\title{
Agricultural land conversion and its effects on farmers in contemporary Vietnam
}

\author{
Nguyen Van Suu
}

\begin{abstract}
Mớ $i$, the name given to the economic reforms initiated in 1986 in Vietnam, has renewed the party-state's ambitious scheme of industrialization and has intensified the process of urbanization in Vietnam. A large area of land has been converted for these purposes, with various effects on both the state and society. This article sheds light on how land conversion has resulted in farmers' resistance and in what way and to what extent it has transformed their livelihoods in the transitional context of contemporary Vietnam. The article argues that agricultural land use rights remain an important asset for Vietnamese farmers, containing great value and meaning for them besides forming a means of production and therefore a source of income. Because the contemporary land tenure system has not yet recognized an adequate level of private property in relation to land, agricultural land conversion often becomes a contested issue and has often disrupted farmers' traditional livelihoods, forcing them to face insecure livelihood prospect.
\end{abstract}

Keywords: contemporary Vietnam, industrial zones, industrialization, land rights appropriation, livelihood conflicts

After a long struggle against French domination, the 1954 victory of the Việt Minh in Điện Biên Phủ did not result in a total independence for Vietnam but in the partition of the country in two zones, each of which would follow a different path of political and economic development. The Democratic Republic of Vietnam in the north tried, with the international support of it communist allies, to build socialism through a centrally planned economy while the Republic of Vietnam in the south favored a more market-oriented economy, built under the auspices of the United States.
This set the scene for the struggle for national unification under the leadership of Vietnamese Communist Party that has become known under different names: "The war of resistance against America" by the Vietnamese side-the "Vietnam War" by the American side. Following the unification of Vietnam in 1975, the Socialist Republic of Vietnam was declared on 2 July 1976. Shortly after Vietnam faced two more severe wars: one against the Khmer Rouge in the south, from 1978 to 1989, and one with the Chinese in the north in 1979. The human and economic costs of these wars for Vietnam were high; more- 
over, they critically damaged the country's international diplomatic and trading relations. The suffering from these prolonged wars was worsened by the increasing ineffectiveness of the centrally planned economy in addition to the reduction of foreign aid after 1975 . Combined, these factors pushed Vietnam into a major economic crisis, starting in the late 1970s.

At the same time the international situation changed. Vietnam's fraternal socialist countries like China, the Soviet Union, and the countries of Eastern Europe commenced reforms while cold war tensions reduced and the pace of globalization increased. In such a domestic and international context, the Communist Party of Vietnam, at its Sixth Party Congress in 1986, officially launched its economic reform program of Đổi Mới ("renovation"), though piecemeal reforms in agricultural production and other sectors had already emerged earlier, initiated by local farmers and cadres and later adopted by the central party-state in the early 1980s (Kerkvliet 1995, 2005).

Though trying to maintain political stability and territorial integrity, the Vietnamese partystate has pushed strongly toward the transformation of the centrally planned economy to a more market-oriented model, which increasingly treats private, foreign, and joint-venture economies as key pillars of the national economy. Consequently, this has changed the relationship between the party-state and society in a number of fields, including with regard to the control of agricultural land and other natural resources. Another key aspect of Đổi Mớis agenda was a fundamental shift in the party-state's foreign relation policy toward a normalization of Vietnam's diplomatic and trading relations with China, the United States, and other countries since the early 1990s.

After over twenty years of Đổi Mới, Vietnam has been praised by various domestic and international institutions for its "impressive" achievements in socio-economic development and poverty reduction and its gradual liberalization and market diversification combined with a commitment to equality. In this context, this article examines why, how, and to what extent the Vietnamese state has appropriated land, espe- cially agricultural land, for the processes of industrialization and urbanization and what the impacts of this are on farmers in contemporary Vietnam.

\section{Land rights in Vietnam}

In the 1980s Vietnam, just as Laos and China, began clarifying the issues of land ownership, control, and use rights in the state land tenure legislation. A crucial point of the new land tenure regime that has emerged since is the state's division of land rights into three key categories, held by different entities: ownership rights (quyên sở hĩu) belong to the entire people, control rights (quyên quán lý) are under the state, and use rights (quyên sứ dụng) are allocated to individuals, family households, and organizations for a certain period of time, depending on the type of land. Although this process of agricultural decollectivization started in the early 1980s, land use rights were only officially allocated to individuals, family households, and organizations in 1988, in accordance with the 1988 Land Law and with the Party Political Bureau's Resolution 10. In 1993, land use rights were officially reallocated in accordance with the 1993 revised Land Law, which also regulated the possible extension of the use time in 2013.

Moreover, since the Seventh Party Congress (1991), and particularly since the Eight Party Congress (1996), industrialization-"công nghiệp hóa"-has once more become an ambitious scheme of the party-state, aiming to turn Vietnam into an industrialized country by 2020 . To turn Vietnam's traditional agricultural economy into a modern industrial one, the party-state sees it necessary to convert agricultural land to create space for industrialization and urbanization.

As in China, industrialization in Vietnam is accompanied by a rapid process of urbanization. The seizure of land that has taken place in the past 20 years for these purposes comes roughly in two forms. The first is land seizure for the state, collective, national defense, and security purposes. In this case, relevant state authorities directly plan the location, the area, and level of 
compensation and implement the seizure to meet targeted purposes without consulting the holders of the land use rights. This originates from a rationale that all land in Vietnam belongs to the entire people, which is represented by the socialist state, and therefore the state allocates (giao) rather than gives (cho)-land use rights to individuals, households, and organizations for certain period of time. When the state needs land, it has the power and the right to seize (thu hôi) use rights on the land, and offer the holders a level of compensation for their forgone land use rights alongside compensation for what they may have cultivated or constructed on the fields. The question of what is a reasonable level of economic compensation is often the key point creating conflict between the state officials in charge of land appropriation and the villagers who hold the use rights on the appropriated land.

The second, a new form that emerged with the 2003 revised Land Law, is land seizure for purposes of economic development, which in many cases involves the transfer of land use rights from farmers to private entrepreneurs and other commercial parties. The latter have to work with relevant state institutions and the holders of land use rights to reach agreements about the transfer or appropriation of land use rights prior to the relevant authorities' official decision making about any specific land seizure. In contrast to the first, this second form of land appropriation does give the holders of land use rights, who are usually farmers, a say in the land conversion process.

Conflicts over appropriation of and compensation for land use rights remain burning issues in Vietnam. In 2008 the central government explored new institutional ways of land seizure, including establishing a Company of Land Seizure and Compensation and allowing the local authorities to set up a Centre for Land Seizure and Compensation in the hope to build mediating institutions between the holders of land use rights and other parties wanting to use the land.

During the past 20 years, industrialization and urbanization in Vietnam have encroached a large area of land. However, to this date, Viet- nam has no accurate and systematic figures on the total area of land, especially agricultural land, that has been appropriated since the early 1990s for these purposes nationwide. The piecemeal data show that on the national scale, from 1991 to $2003,697,417$ hectares of land have been seized to build industrial zones, construct infrastructure, and serve other non-agricultural purposes (Lê Du Phong 2005: 9). In 2005 Nhân Dân newspaper, the Vietnam Communist Party's mouthpiece, reported that approximately 200,000 hectares of agricultural land were being appropriated each year for non-agricultural purposes nationwide (Báo Nhân Dân 2005). Various other materials provide complementary figures. One source from the Ministry of Agricultural and Rural Development, as reported by the Communist Review, a theoretical and political agency of the Communist Party of Vietnam, claimed that in a five year period (2001-2005), 366,000 hectares of agricultural land had been converted into urban and industrial land by the central government. This amount accounted for 4 percent of the total area of Vietnam's agricultural land. In the sixteen provinces that have converted particularly sizeable areas-including Tiền Giang (20,380 hectares), Đông Nai (19,752 hectares), Vĩnh Phúc (5,573 hectares), and Hanoi (7,776 hectares) -89 percent of the appropriated land is agricultural (Tạp chí Cộng Sán 2007). Since 2005 the pace of land conversion has increased, but accurate figures on the areas converted are not yet available.

As previously noted, land is appropriated for industrial sites, urban development, infrastructure construction, recreation (e.g., golf courses), ${ }^{1}$ and other non-agricultural purposes. Among these, land conversion for the building of export-processing zones (khu chếxuất), industrial zones (khu công nghiệp), economic zones (khu kinh tế), and hi-tech zones (khu công nghệcao) accounts for a major percentage. Government bodies, at different levels, often "roll out the red carpets" (trải thám đỏ) to attract foreign and domestic investors by making administrative arrangements easier for them and, in a few cases, by waiving or reducing the land rental fees for a certain period of time. 
In most cases the development of industrial and other economic zones takes place in the flat and fertile arable land that farmers call bờ xôi ruộng mật around the urban areas, especially the large cities, where there is better infrastructure and that are densely populated, rather than in the less fertile, hilly land areas as the former more easily attract entrepreneurs and strongly reduce the government's costs on infrastructure development prior to the entrepreneurs investment. In this case, the government can take a shortcut in terms of reaching its industrialization goals. The farmers whose land use rights are converted are likely to lose out in this process of development if they are unfairly compensated and/or unable to form alternative livelihoods.

\section{Land use rights appropriation and its effect on farmers}

Since the early 1990s, land conversion in Vietnam has paved the way for the development of a large number of industrial sites. The first exportprocessing zone was constructed in Ho Chi Minh City in 1991 and since then many more industrial, economic, and hi-tech zones have been planned. By 2005130 large export-processing, industrial, economic, and hi-tech zones under the management of the central government have dotted the country, using 26,517 hectares of land (Vũ Đình Tôn et al. 2007: 50). In addition, there is a variety of small- to medium-size industrial zones and clusters that are managed by city, province, or district governments and that do not appear on the national map of industrial sites (see Ministry of Planning and Investment 2007). Between 2005 and 2010 the government plans to build 128 new large industrial zones on an estimated area of 22,813 hectares (Lê Văn Học 2005: 8). It has officially approved a master plan for the longer-term development of industrial zones that aims to increase the total area of industrial zones to 70,000 hectares of land by 2015 and 80,000 hectares by 2020, excluding a variety of small- to medium-size industrial zones and clusters managed by lower authorities (see Quyết định số 1107/QĐ-TTg). By early 2008, numerous state media reported on Vietnam's celebration of its twenty years of Foreign Investment Law (1987-2007), in which the Ministry of Planning and Investment announced the country's winning of 9,500 projects from eighty-two countries, worth US\$98 billion in investment capital, most of which will go to industrial sites (Báo Kinh Tế Việt Nam 2008).

Conversion of land at such a large scale will affect farmers and generate resistance from them against what they see as corruption and unfair levels of economic compensation. In a number of cases, farmers' resistance to land conversion has not been limited to the type of everyday forms of resistance that Ben Kervliet $(1995,2005)$ documented in local communities during the agricultural collectivization period in North Vietnam, but has turned to forms of public protest, within and outside farmers' home villages, involving discussion, petition, denunciation, gathering, and sometimes violent actions to voice their views and demand their wants (for a detailed discussion of this form of resistance, see Nguyen Van Suu 2007). One example is Đại Lộc ${ }^{2}$ village in Bắc Ninh province, which in 2001 had 2,829 inhabitants, living in 636 households. From 1999 to 2001, the agricultural land use rights of 359 households were seized with the conversion of agricultural land for a new highway and a local industrial zone. As a result, 11 households lost all, over 100 households lost around 90 percent, and many others lost about 50 percent of their allotted agricultural land use rights. Many villagers disagreed with the level of compensation given to them by the government and the corrupt acts conducted by the local cadres in the process of land appropriation. They also went to different levels of state authorities. Upon failing to have their demands addressed and seeing local cadres' misbehave, they took stronger actions and did not allow the village's organizing committee to count the votes on the day of National Assembly Election. Consequently, higher-state officials and police forces interfered to resolve the issue and punish a number of both local cadres and villagers. In the end, the conversion of land had been completed; the villagers whose agricultural land use 
rights were seized did not receive any other economic rights. ${ }^{3}$

Another pervasive effect is the disruption of farmers' traditional livelihoods. As most of the appropriated land is agricultural land in the densely inhabited lowland areas around urban centers, land conversion has also led to increased inequality in access to land use rights among farmer households and especially the loss of traditional livelihoods. Considering the case of Hanoi as an example, industrialization and urbanization have led to a rapid expansion of the city during the past decade. As it is planned, 11,000 hectares of land-mostly annual cropland in rural Hanoi-will between 2000 to 2010 be converted into industrial and urban land for 1,736 projects. It is estimated by the city authorities that this conversion will result in the loss of the traditional employment of 150,000 farmers. In practice, in a five-year period alone (20002004), Hanoi has converted 5,496 hectares of land for 957 projects and this impacts critically on the life and employment of 138,291 households, of which 41,000 are classified as agricultural households (Hông Minh 2005).

As a result, many farmers face insecure livelihoods as they are forced to change their occupation and even their socio-cultural lives. According to the Ministry of Labor, Invalids and Social Affairs estimates, Vietnam's conversion of 366,440 hectares of land between 2001 and 2005 alone affected the lives of 627,495 households, including 950,000 laborers and 2.5 million farmers (Bùi Trân 2007).

Farmers on land targeted for conversion often have few alternative options of work. The resistance arising from individual conflicts over land use rights compensation usually does not last long-in most cases the state is successful in acquiring the land for development objectives. The problem of landless villagers will become more visible in the coming years when their compensation money will have been spent. In addition, agricultural land per capita continues to decrease for various reasons, including demographic increase and agricultural land appropriation. This is not to mention the increased application of machines, new varieties of seeds, fertilizers, and chemicals alongside the development of irrigation systems that have not only improved agricultural productivity but also increasingly reduced the size of the labor force required on a given area of farm land. All these factors result in greater redundancy among the rural labor force.

The social issues related to the high pace of land appropriation during the past 20 years are a source of concern for the party-state. In addition to various piecemeal assessments by different state institutions and NGOs, in 2005 the Vietnamese prime minister assigned the $\mathrm{Na}$ tional Economics University to examine the current income, life, and work situation of the people whose land use rights had been appropriated for purposes of industrialization and urbanization (Lê Du Phong 2005; in 2007 the study was published in book format [Lê Du Phong [chủ biên] 2007]).The study recommended that though appropriation of land for industrialization and urbanization needs be continued, even with a higher pace in the coming years, there are social and economic issues for the state and parties who use the appropriated land to pay attention to (Lê Du Phong 2005: 9). The study covered only some aspects of land conversion and did not analyze how the appropriation of land results in conflicts.

In theory, the government emphasizes the insurance of livelihoods of those whose land rights are appropriated. For example, it regulates that the affected farmers must be provided with a limited fund for job training, and in the case of industrial zone building, the entrepreneurs who use the acquired land are required to employ a certain percentage of the farmers who lost their land rights, and has also planned to export labor forces to foreign countries. One decree (17/2006/ND-CP) even stipulates that farmers who have been required to make way for development projects must be compensated with land, not cash (see Viet Nam News, 9 February 2006: 15). Meanwhile, some researchers urge the state to take steps to balance the interest among the state, land use rights holders, en- 
trepreneurs, and the nation at large in seizing land for purposes of industrialization and urbanization (Lê Du Phong [chủ biên] 2007: 220-22).

However, the situation on the ground is far from ideal as a large portion of the expropriated villagers have no stable job. This problem would deserve greater attention. Tran Duc Vien and colleagues (2005) found that farmers in Hanoi who lost their land right often did not find work in the non-agricultural production sector. In one commune in Hải Dương province, where 220 hectares of agricultural land were acquired for a company to use, the company promised to employ 11,000 laborers of the local commune. It ended up employing only forty-eight workers (Xuân Quang 2004).

In Phú Điền, a peri-urban village of Hanoi, 70 percent of the village agricultural land was seized between 1998 and 2007. Farmers received a large amount of cash for their land loss in addition to a rapid increase of their residential land's exchange value. Although some villagers have engaged in simple, self-employed non-agricultural work such as informal retailing and selling basic foodstuffs, household goods, and services to the migrant laborers and students residing in their community, many other farmers have no work to do after their land is appropriated. ${ }^{4}$

Investors are often only able to employ about 3-5 percent of people whose land has been appropriated (Báo Nhân Dân 2005) and often farmers' poor social and human capital, making them unqualified to work in the industrial sector, is blamed for this. According to the Ministry of Labor, Invalids, and Social Affairs, in 2004 alone, 63,760 farmers in northern Vietnam had become jobless due to their agricultural land being appropriated for state programs (quoted in Xuan Quang 2004). According to 2007 data, of the more than 12 million rural households, with nearly 33 million people of working age-accounting for 72 percent of the national labor force-only 3 percent had been trained. ${ }^{5}$

In short, various materials demonstrate that for many farmers, a loss of agricultural land use rights results in a loss of livelihood, potentially creating a vulnerable group in contemporary
Vietnamese society. The conversion of land on the scale at which it has been taking place during the past decade and is planned for the coming years also indicates a change in the partystate's ideology with regard to the relationship between land and farmers. During the revolutionary period, the party-state used to promote the slogan "người cày có ruộng" (land to the tillers) but it now seems to accept a certain level of inequality in access to agricultural land among farmers, with a number of farmers now having no or little agricultural land use rights.

Some Vietnamese researchers endorse this perspective by arguing that this is a necessity suitable to the rules of economic development. They argue that resolutions for landless farmers should concentrate on vocational training and the creation of new jobs and not on equalizing land use rights because it is the time for the state to replace its traditional slogan of "người cày có ruộng" (land to the tillers) with "người lao dộng có việc làm" (jobs for laborers). This is an ideal goal. However, a key question that remains unanswered is what kind of jobs there are for landless farmers. Information on various cases that I have discussed indicates that without more effective policies to reduce the impact of large-scale land conversion, farmers whose agricultural land use rights are ceded might become marginalized in the process of development.

Nguyen Van Suu is a lecturer at the Department of Anthropology, College of Social Sciences and Humanities, Vietnam National University, Hanoi. He has published a number of articles and book chapters on land tenure changes and conflicts over land in Vietnam. His current research project examines the question of how the conversion of agricultural land use rights for industrialization and urbanization has transformed farmers' livelihoods in the peri-urban area of Hanoi.

Email:nvsuu@yahoo.com

Mail address: Department of Anthropology, College of Social Sciences and Humanities, Vietnam National University-Hanoi, 336 Nguyen Trai, Thanh Xuan, Hanoi, Vietnam. 


\section{Notes}

1. Land conversion for golf courses accounts for a large area of agricultural land. As of 2008 Vietnam has 140 golf courses, covering over 38,000 hectares of land in fifty-one provinces and cities. There is a common saying that thousands of Vietnamese farmers have to satisfy their agricultural land, their traditional means of production, for the amusement of a few hundred wealthy people. Since early 2008, when the country's inflation hit a two-figure rate, possibly threatening national food security, the central government has started limiting the issuing of permits for the development of new golf courses.

2. Names of villages have been changed in this article.

3. According to my fieldwork data in 2002.

4. According to my fieldwork data in 2007.

5. According to VUFO-NGO Resource Center's News, 25 June, 2007.

\section{References}

Asian Development Bank. 2006. Industrial and commercial land market processes and their impact on the poor. Making Markets Work Better for the Poor. Discussion Paper no. 14.

Báo Kinh TếViệt Nam. 2008. Foreign investment in Vietnam: A 20-year review." 3 March. https:// www.ven.vn/investment/foreign-investment-invietnam-a-20-year-review.

Báo Nhân Dân. 2005. Tìm lối ra cho nông dân không còn đất. Ngày 16 tháng Tám.

Bộ Lao động - Thương binh và Xã hội. 2006. Số liệu thống kê việc làm và thất nghiệp ở Việt Nam giai đoạn 1996-2005. Hà Nội: Nxb. Lao động Xã hội.

Bùi Trần. 2007. Đất cho nông dân. Thanh Niên, ngày 8 tháng Bảy.

Hông Minh. 2005. Hà Nội giải quyết việc làm cho lao động khu vực chuyển đồi mục đích sử dụng đất. Lao động \& Xã hội, số 270.

Kelly, Phlip F. 2003. Urbanization and the politics of land in the Manila region. Annals of the American Academy of Political and Social Science, vol. 590, Rethinking Sustainable Development, pp. 170-87.
Kerkvliet, Ben. 1995. Village-state relations in Vietnam: The effects of everyday politics on decollectivization. Journal of Asian Studies 54 (2): 396-418.

- 2005. The power of everyday politics: How Vietnamese peasants transformed national policy. Ithaca: Cornell University Press.

Lê Du Phong. 2005. Thực trạng thu nhập, đời sống, việc làm của người có đất bị thu hôi để xây dựng các khu công nghiệp, khu đô thị, xây dựng kết cấu hạ tầng kinh tế - xã hội, nhu câu công cộng và lợi ích quốc gia. Trường Đại học Kinh tế Quốc dân: Đề tài độc lập cấp nhà nước.

Lê Du Phong (chủ biên). 2007. Thu nhập, đời sông, việc làm của người có đât bị thu hôi đề xây dựng các khu công nghiệp, khu đồ thị, kết cấu hạ tầng kinh tế-xã hội, các công trình công cộng phục vụ lợi ích quốc gia. Hà Nội: Nxb. Chính trị Quốc gia.

Lê Văn Học. 2005. Định hướng phát triển các khu công nghiệp ở Việt Nam đến năm 2010. Thông tin Khu Công nghiệp Việt Nam, số 5.

Ministry of Planning and Investment. 2007. A guide for investing in Vietnam's IPs, EPZs and IZs. http://www.khucongnghiep.com.vn.

Nghị quyết số 07-NQ/HNTW của Hội nghị lân thứ Bảy Ban Chấp hành Trung ương Đảng Khóa VII vê Phát triển công nghiệp, công nghệ đến năm 2000 theo hướng công nghiệp hóa, hiện đại hóa đất nước và xây dựng giai cấp công nhân trong giai đoạn mới. Ngày 30 tháng Bảy năm 1994.

Nghị quyết số 15-NQ/TW của Hội nghị lần thứ Năm Ban Chấp hành Trung ương Đảng Khóa IX vể Đẩy nhanh công nghiệp hóa, hiện đại hóa nông nghiệp, nông thôn thời kỳ 2001-2010. Ngày 18 tháng Ba năm 2002.

Nguyen Van Suu. 2004. The politics of land: Inequality in land access and local conflicts in the Red River Delta since Decollectivization. In Social Inequality in Vietnam and the Challenges to Reform, ed. Philip Taylor, 270-96. Singapore: ISEAS. 2006: Phân hóa trong tiếp cận đất đai ở Việt Nam. Tạp chí Dân tộc học, số 3, trang 48-57. 2007. Contending views and conflicts over land in Vietnam's Red River Delta. Journal of Southeast Asian Studies 38 (2): 309-34.

Quốc hội Nước Cộng hòa Xã hội Chủ nghĩa Việt Nam. 1995. Luật Đất Đai. Hà Nội: Nxb. Chính trị Quốc gia.

C 2003. Luật Đất Đai. Hà Nội: Nxb. Chính trị Quốc gia. 
Quyết định số 1107/QĐ-TTg. 2006 (của Thủ tướng Chính phủ) vê việc phê duyệt quy hoạch phát triển các khu công nghiệp ở Việt Nam đến năm 2015 và định hướng đến năm 2020. Ngày 21 tháng Tám.

Rigg, Jonathan, Suriya Veeravongs, Lalida Veeravongs, and Piyawadee Rohitarachoon. 2008. Reconfiguring rural spaces and remaking rural lives in central Thailand. Journal of Southeast Asian Studies 39 (3): 355-81.

Tạp chí Cộng sản. 2007. Tình hình thu hôi đất của nông dân để thực hiện công nghiệp hóa-hiện đại hóa và các giải pháp phát triển. Số 12.

Tran Duc Vien, Nguyen Vinh Quang, and Nguyen Van Dung 2005. Rural-urban land use changes in peri-urban Hanoi. SEARUSYN research report.

Vietnam Development Report. 2008. Social Protec- tion. Joint Donor Report to the Vietnam Consultative Group Meeting, Hanoi, December.

Vụ Quản lý Kiến trúc Quy hoạch. 1998. Quy hoạch, quản lý và phát triên các khu công nghiệp ở Việt Nam. Hà Nội: Nxb. Xây Dựng.

Vũ Đình Tôn, Nguyễn Thị Huyền, and Võ Trọng Thành 2007. Thách thức đối với sinh kế và môi trường sống của người nông dân vùng chuyển đổi đất cho khu công nghiệp. Nghiên cúu Kinh tế, số 351 .

Walker, Kathy Le Mons. 2008. From covert to overt: Everyday peasant politics in China and the implications for transnational agrarian movements. Journal of Agrarian Change 8 (2 and 3): 462-88.

Xuân Quang. 2004. Câu chuyện quản lý: Hai cái “ngắn." Lao Động, số 219, ngày 6 tháng Sáu. 